EUROPA REGIONUM TOM XXIII ROK 2015

DOI: $10.18276 /$ er.2015.23-20

\author{
IWONA BĄK \\ Zachodniopomorski Uniwersytet Technologiczny w Szczecinie
}

\title{
Atrakcyjność środowiska przyrodniczego w województwie zachodniopomorskim a aktywność turystyczna turystów zagranicznych
}

\section{Wprowadzenie}

G unkcjonowanie turystyki, od jej początków po formy współczesne, pozostaje nierozerwalnie związane ze środowiskiem przyrodniczym. Jak wykazują badania ankietowe, większość turystów poszukuje takich miejsc do spędzenia wolnego czasu, które zapewniają spokój, czyste powietrze i możliwość obcowania z naturą (Bąk 2005, s. 75-80). Potrzeba kontaktu człowieka z przyrodą jest cechą wrodzoną, a jej wyrazem we współczesnym, mocno zurbanizowanym świecie jest aktywność turystyczna. Intensywność ruchu turystycznego zależy od wielu czynników. Zdaniem wielu autorów skalę tego ruchu determinuje poziom atrakcyjności turystycznej destynacji. Atrakcyjność turystyczna jest pojęciem złożonym i trudnym do jednoznacznej oceny, ponieważ oprócz istniejących obiektywnie warunków środowiska przyrodniczego, kulturowego czy społecznego, istotną rolę w wartościowaniu odgrywa czynnik psychologiczny (Potocka 2009, s. 19). W literaturze z zakresu turystyki atrakcyjność turystyczną definiuje się jako siłę, z jaką dane miejsce, obiekt lub zjawisko przyciąga odwiedzających lub jako stopień nasycenia wydzielonych układów przestrzennych określonymi czynnikami (Rapacz 2004, s. 57). Do podstawowych czynników zalicza się najczęściej: walory turystyczne, stan zagospodarowania turystycznego i stopień dostępności komunikacyjnej. Często do wymienionych powyżej czynników dodaje się jeszcze jeden, dotyczący poziomu zanieczyszczenia środowiska przyrodniczego (Jedlińska, Szubert-Zarzeczny 1994; Bąk 2007). 
Ogólnoświatową zmianę w mentalności współczesnego człowieka, zwaną potocznie „powrotem do natury”, można uznać za fenomen końca XX wieku. W latach osiemdziesiątych na forum międzynarodowym odbyły się pierwsze dyskusje na temat konieczności zmiany podejścia do rozwoju turystyki. Pojawiły się wówczas terminy „turystyki łagodnej i zrównoważonej”, która dotyczy szeroko pojętej koncepcji rozwoju turystycznego przyjaznego środowisku w regionach wiejskich oraz miastach, w małych ośrodkach turystycznych oraz wielkich centrach rozrywkowych i wypoczynkowych itp., koncepcji, która dotyczy wszystkich znanych rodzajów turystyki po dokonaniu stosownej ich „ekologizacji” (Zaręba 2000). Również w Polsce obserwuje się nowe tendencje dotyczące rozwoju turystyki przyjaznej środowisku. Władze wielu gmin i miejscowości turystycznych wychodzą z założenia, że jedynie czyste środowisko i nieskażona przyroda mogą przyciągnąć turystów i zachęcić ich do ponownego odwiedzenia regionu. Inwestują więc w poprawę czystości wód i powietrza, tworzą szlaki turystyczne, dbają o szatę roślinną itp.

Celem artykułu jest analiza przestrzennego zróżnicowania poziomu atrakcyjności powiatów województwa zachodniopomorskiego z punktu widzenia możliwości rozwoju w nich turystyki przyjaznej środowisku naturalnemu. Ponadto poruszono tu zagadnienie wpływu atrakcyjności turystycznej obszaru recepcji turystycznej na intensywność zagranicznego ruchu turystycznego. Jest to zagadnienie bardzo istotne $\mathrm{z}$ ekonomicznego punktu widzenia. Turyści zagraniczni, dokonując wydatków na różnego rodzaju dobra i usługi turystyczne, stanowią źródło przychodów i tym samym stają się istotnym elementem rozwoju społeczno-gospodarczego destynacji.

\section{Przyrodnicze walory turystyczne województwa zachodniopomorskiego}

Województwo zachodniopomorskie ze swoim potencjałem turystycznym może stać się w najbliższej przyszłości jednym z najbardziej atrakcyjnych euroregionów, charakteryzuje się bowiem występowaniem atrakcyjnych walorów turystycznych, zwłaszcza naturalnych. Posiada urozmaicone wybrzeże morskie z czystymi plażami, jeziora, rzeki, zwarte kompleksy leśne. W 2012 roku na jego terenie znajdował się 1 park narodowy, 116 rezerwatów i 5 parków krajobrazowych. Łączna powierzchnia obszarów o szczególnych walorach przyrodniczych stanowiła $21,1 \%$ powierzchni województwa, a na 1 mieszkańca przypadało 
$2803 \mathrm{~m}^{2}$ takich obszarów, wobec $2634 \mathrm{~m}^{2} \mathrm{w}$ kraju. Podczas spływów kajakowych i wycieczek można zobaczyć zabytkowe młyny i elektrownie wodne, największe w Europie wrzosowiska, zabytki architektury sakralnej, słowiańskie grodziska, bunkry, zapory i inne pozostałości umocnień Wału Pomorskiego, a także rzadkie gatunki zwierząt (Turystyka... 2014, s. 1). Ponadto atrakcyjność województwa zwiększają walory uzdrowiskowe takich miejscowości jak: Kamień Pomorski, Kołobrzeg i Połczyn Zdrój, gdzie występują naturalne pokłady borowiny i źródła solankowe.

Wiele zachodniopomorskich miejscowości turystycznych posiada znaczenie międzynarodowe i uzdrowiskowe. Potwierdzeniem dużej atrakcyjności obszarów województwa pod względem turystycznym jest jego udział w krajowej bazie turystycznej. W województwie zlokalizowana jest największa baza noclegowa w kraju (17,6\% miejsc noclegowych Polski), rozmieszczona w 1293 obiektach turystycznych $(13,2 \%$ obiektów w kraju). Więcej obiektów noclegowych w 2013 roku posiadało jedynie województwo pomorskie (14,7\% obiektów w Polsce) i województwo małopolskie (14,3\% obiektów w Polsce) ${ }^{1}$.

\section{Turyści zagraniczni w województwie zachodniopomorskim}

Wśród osób nocujących w turystycznych obiektach zbiorowego zakwaterowania istotną grupę stanowili turyści zagraniczni. W 2013 roku województwo zachodniopomorskie odwiedziło 501,8 tys. cudzoziemców, czyli $24 \%$ wszystkich turystów korzystających z bazy noclegowej. Niemal trzy czwarte gości zagranicznych korzystało z noclegów w obiektach hotelowych $(72,8 \%$ wobec 69,8\% w 2012 r.). Spośród pozostałych rodzajów turystycznych obiektów zbiorowego i indywidualnego zakwaterowania najcześciej wykorzystywali ośrodki wczasowe (12,1\% wobec $13,9 \%$ w 2012 r. $)^{2}$.

W ciagu ostatniej dekady liczba turystów zagranicznych odwiedzających województwo zachodniopomorskie wzrosła o 165 tys., tj. o 48,9\% (tab. 1). Obcokrajowcy najczęściej korzystali z obiektów zlokalizowanych w powiecie kołobrzeskim, mieście Szczecinie, mieście Świnoujście oraz powiecie kamieńskim. W jedenastu powiatach odnotowano wzrost gości zza granicy w ciąu badanej dekady, od 10,8\% w Koszalinie do 21,80\% w powiecie łobeskim, w którym co

\footnotetext{
${ }^{1}$ Obliczenia własne na podstawie (Turystyka ...2014).

${ }^{2}$ Obliczenia własne na podstawie (Turystyka ...2014).
} 
prawda liczba obcokrajowców korzystających z bazy noclegowej nie przekraczała $0,1 \%$ wszystkich korzystających z noclegów w województwie. Pozytywnie w tym względzie wyróżnia się miasto Świnoujście, gdzie w roku 2013 w porównaniu z 2003 udział turystów zagranicznych korzystających z bazy noclegowej zwiększył się dwukrotnie - z 9\% do 18,7\%. W dziesięciu powiatach zaobserwowano spadek odwiedzających w ciągu badanej dekady. Najdotkliwiej dotknął on powiat pyrzycki, który w 2013 r. odwiedziło tylko 40 turystów zagranicznych, wobec 780 w 2003 r. (spadek o 94,9\%). Istotne spadki obcokrajowców odnotowano również w powiatach: świdwińskim (spadek o 52,7\%), szczecineckim (spadek o 49,2\%), wałeckim (spadek o 37,4\%), stargardzkim (spadek o $37,4 \%$ ) i goleniowskim (spadek o 35,8\%).

Tabela 1

Turyści zagraniczni korzystający z noclegów w powiatach województwa zachodniopomorskiego w latach 2003 i 2012-2013

\begin{tabular}{|l|r|r|r|r|r|r|r|}
\hline \multirow{2}{*}{ Powiaty } & \multicolumn{2}{|c|}{2003} & \multicolumn{2}{|c|}{2012} & \multicolumn{3}{|c|}{2013} \\
\cline { 2 - 8 } & \multicolumn{1}{|c|}{ liczba } & \multicolumn{1}{c|}{$\mathrm{W} \%$} & \multicolumn{1}{c|}{ liczba } & \multicolumn{1}{c|}{ \% } & \multicolumn{1}{c|}{ liczba } & \multicolumn{1}{c|}{ \% } & $2003=100$ \\
\hline województwo & 337004 & 100,0 & 462608 & 100,0 & 501830 & 100,0 & 148,9 \\
\hline białogardzki & 1014 & 0,3 & 919 & 0,2 & 851 & 0,2 & 83,9 \\
\hline choszczeński & 61 & 0,0 & 444 & 0,1 & 327 & 0,1 & 536,1 \\
\hline drawski & 1494 & 0,4 & 2078 & 0,4 & 1869 & 0,4 & 125,1 \\
\hline goleniowski & 1316 & 0,4 & 630 & 0,1 & 845 & 0,2 & 64,2 \\
\hline gryficki & 12334 & 3,7 & 18715 & 4,0 & 19256 & 3,8 & 156,1 \\
\hline gryfiński & 3805 & 1,1 & 3799 & 0,8 & 3470 & 0,7 & 91,2 \\
\hline kamieński & 31461 & 9,3 & 45046 & 9,7 & 50659 & 10,1 & 161,0 \\
\hline kołobrzeski & 76150 & 22,6 & 132852 & 28,7 & 148065 & 29,5 & 194,4 \\
\hline koszaliński & 9065 & 2,7 & 12995 & 2,8 & 14381 & 2,9 & 158,6 \\
\hline łobeski & 15 & 0,0 & 47 & 0,0 & 342 & 0,1 & 2280,0 \\
\hline myśliborski & 4068 & 1,2 & 2297 & 0,5 & 3007 & 0,6 & 73,9 \\
\hline policki & 774 & 0,2 & 6739 & 1,5 & 6898 & 1,4 & 891,2 \\
\hline pyrzycki & 780 & 0,2 & 67 & 0,0 & 40 & 0,0 & 5,1 \\
\hline sławieński & 2034 & 0,6 & 10039 & 2,2 & 7864 & 1,6 & 386,6 \\
\hline stargardzki & 6823 & 2,0 & 4169 & 0,9 & 4274 & 0,9 & 62,6 \\
\hline szczecinecki & 3539 & 1,1 & 1690 & 0,4 & 1798 & 0,4 & 50,8 \\
\hline świdwiński & 1905 & 0,6 & 1229 & 0,3 & 902 & 0,2 & 47,3 \\
\hline wałecki & 2958 & 0,9 & 2163 & 0,5 & 1851 & 0,4 & 62,6 \\
\hline Koszalin & 4900 & 1,5 & 5102 & 1,1 & 5427 & 1,1 & 110,8 \\
\hline Szczecin & 142178 & 42,2 & 131575 & 28,4 & 135650 & 27,0 & 95,4 \\
\hline Świnoujście & 30330 & 9,0 & 80013 & 17,3 & 94054 & 18,7 & 310,1 \\
\hline
\end{tabular}

Źródło: opracowanie własne na podstawie: (Turystyka ... 2004; Turystyka ...2014).

O zróżnicowaniu ruchu turystów zagranicznych w poszczególnych jednostkach terytorialnych świadczy poziom wskaźnika Charvata (liczba udzielonych noclegów przypadająca na 1000 mieszkańców). Analiza tego wskaźnika wskazu- 
je, że najpopularniejsze wśród turystów zagranicznych był powiat kołobrzeski oraz miasto Świnoujście, w których na 1000 mieszkańców przypadało ponad 14 tys. noclegów udzielonych obcokrajowcom. Analiza wartości wskaźnika Charvata ukazała znaczne zróżnicowanie przestrzenne, współczynnik zmienności przekroczył 218\%. Średnia liczba noclegów udzielonych turystom zagranicznym w 2013 r. wyniosła 2021 na 1000 mieszkańców, natomiast wartość mediany wskazuje, że w połowie badanych powiatów liczba udzielonych noclegów nie przekroczyła 133. W czterech powiatach (kamieńskim, gryfickim, koszalińskim i sławieńskim) wskaźnik Charvata przekroczył 1000, a w siedmiu nie przekroczył nawet 80 noclegów na 1000 mieszkańców.

Województwo zachodniopomorskie w latach 2012-2013 najczęściej odwiedzali obywatele państw należących do Unii Europejskiej. Wśród odwiedzających ten region najwięcej było turystów z Niemiec, którzy stanowili w 2013 roku prawie $78 \%$ zagranicznych gości korzystających z turystycznych obiektów noclegowych. Niespełna $11 \%$ odwiedzających stanowili obywatele państw skandynawskich, tj. Danii (6\%), Szwecji (3\%) i Norwegii (1,8\%). Udział turystów z pozostałych państw był mało znaczący i wynosił od 1,42\% do $0,32 \%$.

\section{Materiał i metoda badawcza}

Do analizy przestrzennego zróżnicowania poziomu atrakcyjności turystycznej powiatów województwa zachodniopomorskiego w 2013 roku wykorzystano wstępnie 14 cech (wskaźników) charakteryzujących z jednej strony atrakcyjność środowiska przyrodniczego (stymulanty), a z drugiej mierzących poziom jego zanieczyszczenia (destymulanty) ${ }^{3}$ :

$X_{1}-$ lesistość w \%,

$X_{2}$ - powierzchnia o szczególnych walorach przyrodniczych prawnie chronionych $\mathrm{w} \%$ powierzchni ogółem,

$X_{3}$ - pomniki przyrody na $1 \mathrm{~km}^{2}$,

$X_{4}$ - ścieki przemysłowe i komunalne ogółem wymagające oczyszczenia w hm ${ }^{3}$ na $1 \mathrm{~km}^{2}$,

$X_{5}$ - pobór wody ogółem w $\mathrm{hm}^{3}$ na $1 \mathrm{~km}^{2}$,

$X_{6}$ - ludność korzystająca z oczyszczalni ścieków w \% ludności ogółem,

\footnotetext{
${ }^{3}$ Doboru cech diagnostycznych do klasyfikacji obiektów z punktu widzenia atrakcyjności turystycznej dokonano m.in. w pracach: (Bąk 2007, 2012).
} 
$X_{7}$ - emisja zanieczyszczeń pyłowych powietrza z zakładów szczególnie uciążliwych w tysiącach ton na $1 \mathrm{~km}^{2}$,

$X_{8}$ - emisja zanieczyszczeń gazowych powietrza z zakładów szczególnie uciążliwych w tysiącach ton na $1 \mathrm{~km}^{2}$,

$X_{9}$ - zanieczyszczenia pyłowe powietrza zatrzymane w urządzeniach do redukcji zanieczyszczeń w \% zanieczyszczeń wytworzonych,

$X_{10}$ - zanieczyszczenia gazowe powietrza zatrzymane w urządzeniach do redukcji zanieczyszczeń w \% zanieczyszczeń wytworzonych,

$X_{11}$ - odpady (z wyłączeniem komunalnych) wytworzone w ciągu roku ogółem w tonach na $1 \mathrm{~km}^{2}$,

$X_{12}$ - odpady komunalne zebrane w ciagu roku w tys. ton na $1 \mathrm{~km}^{2}$,

$X_{13}$ - nakłady na środki trwałe służące ochronie środowiska w zł na 1 mieszkańca,

$X_{14}$ - nakłady na środki trwałe służące gospodarce wodnej w zł na 1 mieszkańca.

Badając podobieństwo zmiennych za pomocą współczynników korelacji zauważono występowanie bardzo silnej zależności między niektórymi cechami. W związku z tym do ostatecznego doboru cech diagnostycznych zastosowano dodatkowo podejście formalne - metodę parametryczną zaproponowaną przez Hellwiga (Nowak 1990, s. 28-29). W tym celu wyznaczono macierz współczynników korelacji między potencjalnymi cechami diagnostycznymi a następnie wyznaczono cechy centralne i izolowane, które utworzyły bazowy układ cech. $\mathrm{W}$ ten sposób do dalszej analizy zaklasyfikowano następujące cechy: $X_{2}, X_{3}, X_{4}$, $X_{9}, X_{10,}, X_{14}$.

W celu stworzenia rankingu powiatów zastosowano taksonomiczny miernik rozwoju oparty na sumach standaryzowanych. Zastosowanie taksonomicznego miernika pozwala na przeprowadzenie porównań rozwoju obiektów wielocechowych. Im większą wartość przyjmuje miernik, tym wyższym poziomem zjawiska odznacza się obiekt. Konstrukcja zmiennych syntetycznych wykorzystuje różne sposoby normalizacji cech diagnostycznych (Sobczyk, s. 89-96). $\mathrm{W}$ artykule zastosowano standaryzację cech. Standaryzacja wartości cech diagnostycznych powoduje, że przy budowie miernika uważa się je za jednakowo ważne. Opierając się na metodzie sum standaryzowanych konstrukcja syntetycznego miernika wykorzystuje następującą formułę:

$$
g_{i}=\frac{1}{m}\left[\sum_{j \in S} \frac{y_{i j}-\bar{y}_{j}}{s_{j}}+\sum_{j \in D} \frac{\bar{y}_{j}-y_{i j}}{s_{j}}\right],
$$


gdzie: $S$ - zbiór numerów cech będących stymulantami, $D$ - zbiór numerów destymulant, $\bar{y}_{j}$ - średnia arytmetyczna cech, $s_{j}$ - odchylenie standardowe cech.

W kolejnym kroku budowy miernika stosuje się następujące przekształcenia:

$$
g_{i}^{\prime}=g_{i}-\min _{i} g_{i} g_{i}^{\prime \prime}=\frac{g_{i}^{\prime}}{\max _{i} g_{i}^{\prime}}, \quad i=1, \ldots, n \text {. }
$$

Wykorzystanie wzoru na $g_{i}^{\prime}$ powoduje przesunięcie skali miernika $g_{i}$ do punktu zerowego, a przekształcenie następne $g_{i}^{\prime \prime}$ prowadzi do ustalenia górnego kresu syntetycznego miernika równego 1 . Ostatecznie syntetyczne mierniki jakości mieszczą się $\mathrm{w}$ przedziale $<0,1>$. Na podstawie wartości miernika syntetycznego można wyodrębnić cztery grupy typologiczne, obejmujące obiekty o wartościach miernika z następujących przedziałów:

grupa 1: $g_{i}^{\prime \prime} \geq \overline{g_{i}^{\prime \prime}}+s_{g_{i}^{\prime \prime}}$, grupa 2: $\overline{g_{i}^{\prime \prime}}+s_{g_{i}^{\prime \prime}}>g_{i}^{\prime \prime}>\overline{g_{i}^{\prime \prime}}$, grupa $3: \overline{g_{i}^{\prime \prime}}>g_{i}^{\prime \prime} \geq \overline{g_{i}^{\prime \prime}}-s_{g_{i}^{\prime \prime}}$, grupa $4: g_{i}^{\prime \prime}<\overline{g_{i}^{\prime \prime}}-s_{g_{i}^{\prime \prime}}$,

gdzie: $g_{i}$ - syntetyczny miernik rozwoju dla i-tego obiektu, $\overline{g_{i}^{\prime \prime}}-$ wartość przeciętna syntetycznego miernika rozwoju, $s_{g_{i}}$ - odchylenie standardowe syntetycznego miernika rozwoju.

\section{Ranking powiatów województwa zachodniopomorskiego pod względem atrakcyjności środowiska przyrodniczego}

W tabeli 2 przedstawiono wyniki klasyfikacji oraz grupy typologiczne powiatów województwa zachodniopomorskiego pod względem atrakcyjności środowiska przyrodniczego.

Jak wynika z tabeli większość powiatów województwa zachodniopomorskiego w 2013 roku osiagnęła poziom atrakcyjności środowiska przyrodniczego powyżej przeciętnego w województwie. Najbardziej atrakcyjne turystycznie okazały się trzy powiaty: gryfiński, Koszalin i wałecki. Na wysoki poziom taksonomicznego miernika rozwoju w tych powiatach największy wpływ miały następujące czynniki: duża powierzchnia o szczególnych walorach przyrodniczych prawnie chroniona $\mathrm{w} \%$ powierzchni ogółem, duża liczba pomników przyrody, wysokie nakłady na środki trwałe służące gospodarce wodnej w zł na 1 mieszkańca, a także duża dbałość o środowisko przyrodnicze. W wymienionych powiatach odnotowano najwyższe 
wskaźniki dotyczące udziału zatrzymanych w urządzeniach do redukcji zanieczyszczeń powietrza w \% zanieczyszczeń wytworzonych.

Tabela 2

Kolejność powiatów pod względem taksonomicznego miernika poziomu atrakcyjności środowiska przyrodniczego w 2013 roku

\begin{tabular}{|c|c|c|c|}
\hline Numer miejsca & Powiat & Wartość miernika $g_{i}$ & Nr grupy typologicznej \\
\hline 1 & gryfiński & 1,0000 & \multirow{3}{*}{$\begin{array}{l}\text { I } \\
\text { (bardzo atrakcyjne) }\end{array}$} \\
\hline 2 & Koszalin & 0,9900 & \\
\hline 3 & wałecki & 0,9770 & \\
\hline 4 & myśliborski & 0,8251 & \multirow{9}{*}{$\begin{array}{l}\text { II } \\
\text { (atrakcyjne) }\end{array}$} \\
\hline 5 & $\begin{array}{l}\text { drawski } \\
\end{array}$ & 0,8189 & \\
\hline 6 & choszczeński & 0,7597 & \\
\hline 7 & goleniowski & 0,7145 & \\
\hline 8 & koszaliński & 0,7008 & \\
\hline 9 & kołobrzeski & 0,6818 & \\
\hline 10 & szczecinecki & 0,6569 & \\
\hline 11 & policki & 0,5943 & \\
\hline 12 & stargardzki & 0,5868 & \\
\hline 13 & świdwiński & 0,4778 & \multirow{5}{*}{$\begin{array}{l}\text { III } \\
\text { (przeciętnie atrakcyjne) }\end{array}$} \\
\hline 14 & gryficki & 0,4444 & \\
\hline 15 & białogardzki & 0,4164 & \\
\hline 16 & sławieński & 0,3542 & \\
\hline 17 & lobeski & 0,3112 & \\
\hline 18 & kamieński & 0,2809 & \multirow{4}{*}{$\begin{array}{l}\text { IV } \\
\text { (nieatrakcyjne) }\end{array}$} \\
\hline 19 & Świnoujście & 0,2441 & \\
\hline 20 & Szczecin & 0,1437 & \\
\hline 21 & pyrzycki & 0,0000 & \\
\hline
\end{tabular}

Źródło: obliczenia własne.

Druga $\mathrm{z}$ wyodrębnionych grup jest najliczniejsza, gdyż obejmuje niespełna $43 \%$ badanych jednostek przestrzennych. Wyodrębnione w ramach tej grupy powiaty posiadają zbliżony poziom stanu środowiska przyrodniczego. Najniższym poziomem atrakcyjności charakteryzują się cztery powiaty. Można je traktować jako obiekty, które ze względu na przyjęte cechy charakteryzują się stosunkowo niską atrakcyjnością środowiska naturalnego i jednocześnie wysokim stopniem jego zanieczyszczenia.

W celu ustalenia siły związku między poziomem atrakcyjności środowiska naturalnego powiatów województwa zachodniopomorskiego a aktywnością turystyczną mierzoną liczbą przyjazdów turystów zagranicznych wykorzystano współczynnik korelacji liniowej Pearsona. Obliczenia dokonano na podstawie wyznaczonych wartości miernika syntetycznego atrakcyjności dla poszczególnych powiatów i liczby turystów zagranicznych korzystających z noclegów w 2013 r. Wyznaczona wartość współczynnika równa -0,33 świadczy o umiar- 
kowanej ujemnej zależności pomiędzy badanymi zmiennymi. Okazuje się, że ponad $62 \%$ obcokrajowców odwiedza powiaty należące do III i IV grupy typologicznej, czyli o niskiej lub nawet złej jakości środowiska naturalnego. Natomiast z noclegów w regionach o najlepszej jakości (I grupa) korzysta jednie $2,5 \%$ gości zagranicznych. Oznacza to, że dla obcokrajowców odwiedzających województwo zachodniopomorskie stan środowiska przyrodniczego ma niewielkie znaczenie, a wpływ na ich decyzje dotyczące odwiedzin mają niewątpliwie inne czynniki, np. położenie nadmorskie powiatów, wielkość i znaczenie dużych miast, rozwój gospodarczy danego regionu ${ }^{4}$.

\section{Podsumowanie}

W pracy dokonano próby klasyfikacji powiatów województwa zachodniopomorskiego pod względem atrakcyjności środowiska naturalnego, wykazano w tym zakresie duże przestrzenne zróżnicowanie między powiatami. Nie wpływa to jednak na rozkład przestrzenny zagranicznego ruchu turystycznego. Wyniki potwierdzają znane tendencje, dotyczące koncentracji zagranicznego ruchu turystycznego w miastach i miejscach o dobrej dostępności komunikacyjnej. Powiaty, dla których miernik syntetyczny osiagnął najwyższe wartości wcale nie są bardziej popularne od tych, które charakteryzują się niższą jakością środowiska przyrodniczego. Wynika z tego, że atrakcyjność środowiska przyrodniczego destynacji nie decyduje o wielkości liczby przyjazdów turystów zagranicznych. Często o sile przyciagania turystów do danego regionu decyduje także wiele zróżnicowanych elementów subiektywnych, wśród których dużą rolę odgrywa czynnik psychologiczny powodujący, iż dany region (np. powiat) może być różnie postrzegany przez odwiedzających turystów.

\section{Bibliografia}

Bąk I., Analiza taksonomiczna rozwoju ekoturystyki w województwie zachodniopomorskim, Folia Universitatis Agriculturae Stetinensis, „Oeconomica” nr 245 (44), Wydawnictwo Akademii Rolniczej, Szczecin 2005.

Bąk I., Atrakcyjność regionów turystycznych w Polsce ze szczególnym uwzględnieniem warunków ekologicznych, w: Statystyka w praktyce spoteczno-gospodarczej, red. W. Ostasiewicz, Wydawnictwo Akademii Ekonomicznej we Wrocławiu, Wrocław 2007.

${ }^{4}$ Do podobnych wniosków doszedł K. Niewiadomski (2009, s. 84-86) badając zależności pomiędzy czynnikami środowiska przyrodniczego i gospodarczego a ruchem turystycznym w grupach województw Polski. W konkluzji autor stwierdzil, że rozwijanie ruchu turystycznego na podstawie tylko walorów środowiska przyrodniczego może mieć jedynie ograniczony zakres. 
Bąk I., Przestrzenne zróżnicowanie atrakcyjności produktu turystycznego oraz wykorzystania bazy noclegowej $w$ województwie zachodniopomorskim, Zeszyty Naukowe Uniwersytetu Szczecińskiego nr 664, „Ekonomiczne Problemy Turystyki” nr 2 (18), Wydawnictwo Naukowe Uniwersytetu Szczecińskiego, Szczecin 2012.

Jedlińska M., Szubert Zarzeczny U., Gospodarka turystyczna, Wydawnictwo Akademii Ekonomicznej we Wrocławiu, Wrocław 1994.

Niewiadomski K., Czynniki różnicujace ruch turystyczny w woj. podlaskim, Wiadomości Statystyczne nr 12, GUS, Warszawa 2009.

Nowak E., Metody taksonomiczne w klasyfikacji obiektów społeczno-gospodarczych, PWE, Warszawa 1990.

Ochrona Środowiska 2013, Główny Urząd Statystyczny, Warszawa 2013.

Potocka I., Atrakcyjność turystyczna i metody jej identyfikacji, w: Uwarunkowania i plany rozwoju turystyki. Tom III. Walory turystyczne. Potencjat turystyczny. Plany rozwoju turystyki, red. Z. Młynarczyk, A. Zajadacz, Wydawnictwo Naukowe im. Adama Mickiewicza w Poznaniu, Poznań 2009.

Rapacz A. (red.), Wspótpraca i integracja $w$ turystyce $w$ euroregionie Nysa $w$ perspektywie czlonkostwa $w$ Unii Europejskiej, Wydawnictwo Akademii Ekonomicznej we Wrocławiu, Wrocław 2004.

Sobczyk M. Syntetyczny miernik jakości środowiska przyrodniczego. w: Klasyfikacja $i$ analiza danych, problemy teoretyczne. Taksonomia, z. 2, Wydawnictwo Akademii Ekonomicznej we Wrocławiu, Wrocław 1995.

Turystyka $w$ województwie zachodniopomorskim $w$ latach 2001-2003, Urząd Statystyczny w Szczecinie, Szczecin 2004.

Turystyka w województwie zachodniopomorskim w 2013 r., Urząd Statystyczny w Szczecinie, Szczecin 2014.

Zaręba D., Ekoturystyka. Wyzwania i nadzieje, Wydawnictwo Naukowe PWN, Warszawa 2000 .

\section{The attractiveness of the natural environment of West Pomeranian voivodeship and tourist activity of foreign tourists}

\section{Summary}

The main goal of the article is analysis of spatial diversity of districts attractiveness of West Pomeranian voivodeship from point of view of development of the environmentally-friendly tourism. In the analysis were used the indicators characterizing the attractiveness of the environment and indicators to measure the level of pollution. Classification of districts was made using the taxonomic measure of development based on standardized sums. Furthermore, the article raises the question of the impact of tourism attractiveness of tourist reception area on the intensity of foreign tourism.

Translated by: Iwona Bak 